\title{
Dynamics of ciliate abundance, biomass and community composition in an oligotrophic coastal environment (NW Mediterranean)
}

\author{
Dolors Vaqué ${ }^{1, *}$, Heather A. Blough ${ }^{1}$, Carlos M. Duarte ${ }^{2}$ \\ 'Institut de Ciències del Mar (CSIC), Passeig Joan de Borbó s/n, E-08039 Barcelona, Spain \\ ${ }^{2}$ Centre d'Estudis Avançats de Blanes (CSIC), Cami de Santa Bárbara s/n, E-17300 Blanes, Girona, Spain
}

\begin{abstract}
The importance of ciliates as components of the microbial community of the oligotrophic coastal area of the Bay of Blanes (NW Mediterranean Sea) was examined based on a 3 yr, high resolution study focused on the composition, abundance and biomass of the ciliate community. The most abundant components of the ciliate community were 'oligotrich' ciliates. Naked oligotrichs included heterotrophic genera represented by Halteria, Strombidium, Strobilidium, and Lohmaniella, as well as mixotrophic genera represented by Laboea and Tontonia and loricate ciliates represented by the group of tintinnids. Autotrophic ciliates were represented by the genus Mesodinium. Other, less abundant groups encountered throughout the study period included the orders Scuticociliatida, Pleurostomatida and Prorodontida. Ciliate community abundance and biomass did not show a simple seasonal pattern. Maximum values were observed in spring, following the winter phytoplankton blooms, throughout the study period. Ciliate communities showed significant interannual differences in abundance and cell size. However, total ciliate biomass $\left(\mu \mathrm{g} \mathrm{C} \mathrm{l}^{-1}\right)$ was similar among years. Changes in ciliate abundance and biomass were independent of temperature. Periods with persistent, heavy rainfall, which promotes pulses of allochthonous material from flushed rivers, were characterized by a reduced abundance of ciliates, and increased pico- and nanoplanktonic populations. Cross correlation analysis revealed that bacterial abundance and chlorophyll a (chl a) concentration were both significantly negatively correlated with ciliate abundance, with time lags of $15 \mathrm{~d}$, suggesting a role for ciliates in the control of these communities. Examination of the variability of ciliate abundance and biomass at different time scales revealed a dominant scale of temporal variation in ciliate abundance at about $50 \mathrm{~d}$, similar to that of chl $a$ in the Bay of Blanes, whereas total ciliate biomass $\left(\mathrm{\mu g} \mathrm{Cl}^{-1}\right)$ did not show any dominant scale of variation.
\end{abstract}

KEY WORDS: Coastal area - Ciliate abundance and biomass - Community composition - Rainfall Temporal variabilty

\section{INTRODUCTION}

Ciliates are important components of coastal microbial communities (Pierce \& Turner 1992), where they can play an important role in nutrient and carbon cycling (Azam et al. 1983, Sherr et al. 1986, FerrierPagès \& Rassoulzadegan 1994, Dolan \& Marrasé 1995). The abundance, biomass and composition of coastal microbial communities (i.e. phytoplankton, bacterioplankton, and protists) should be much more variable

\footnotetext{
•E-mail: dolors@icm.csic.es
}

than those of open-sea communities, due to the greater variability in factors influencing their growth (e.g. temperature, salinity, turbulence, water turbidity) characteristic of coastal waters (Nielsen \& Kiørboe 1991).

The Bay of Blanes (Catalan coast, NW Mediterranean Sea) is a heterotrophic system during most of the year, with primary production exceeding community respiration only during phytoplankton blooms (Satta et al. 1996). The Bay of Blanes is characterized by considerable environmental variability (Cebriàn et al. 1996). This variability results from a number of processes, including intermittent pulses of allochthonous material inputs from rivers, and the effects of flow 
modifications by an adjacent submarine canyon (Masó et al. 1990, Masó \& Tintoré 1991). The environmental variability characteristic of the Bay of Blanes should result in a similarly large variability in the pelagic microbial communities. Ciliate communities may respond to environmental variability through changes in abundance, biomass and composition, but these responses may be masked by the effects of the interactions of the ciliate communities with other planktonic communities.

Long-term studies of the distribution of ciliate communities in coastal waters and their response to physical and biological forcing are few, as most studies refer to a 1 or 2 yr period (e.g. Smetacek 1981, Nielsen \& Kiørboe 1991, Bernard \& Rassoulzadegan 1994, Ferrier-Pagès \& Rassoulzadegan 1994). To extend our knowledge of the temporal patterns of ciliate abundance, biomass and composition on the NW Mediterranean coast, we conducted a 3 yr intensive sampling program in the oligotrophic coastal area of the Bay of Blanes. The primary goal of the study was to describe the pattern of seasonal and annual changes in ciliate community structure, density and biomass, with a temporal resolution ranging between $1 \mathrm{~d}$ and $1 \mathrm{wk}$. We also assessed the relationship between the changes observed and environmental and biological forcing. In particular, we examined the relationship between changes in the ciliate community and temperature (which showed a persistent seasonal pattern) and rainfall (as an example of sporadic events which produced pulses of organic and inorganic matter). Biological forcing was assessed through examination of the relationships among ciliate abundance and chlorophyll a (chl a) concentration, and the abundance of bacteria and heterotrophic nanoflagellates. Finally, we characterized the dominant scales of temporal variation in ciliate abundance and biomass.

\section{MATERIALS AND METHODS}

The study was conducted in the Bay of Blanes (NW Mediterranean Sea; Fig. 1), an exposed bay with a relatively steep slope $(\sim 2 \%)$, which receives intermittent discharge from the Tordera River after storm periods, as well as some urban sewage and runoff (cf. Cebriàn et al. 1996). Subsurface (-0.5 m) samples were collected from March 1992 to February 1995, at a $12 \mathrm{~m}$ deep fixed station $\left(41^{\circ} 39.90^{\prime} \mathrm{N}, 2^{\circ} 48.03^{\prime} \mathrm{E}\right)$. The samples were collected twice a week from March 1992 to February 1993, and once a week from March 1993 to February 1995. Sampling frequency was increased (daily or 3 times/week) during phytoplankton blooms. Subsurface $(-0.5 \mathrm{~m})$ water samples were collected in $5 \mathrm{l}$ bottles from an outboard motor boat, and kept refrigerated until reaching the laboratory (30 to 60 min).

Subsurface temperature $(-0.5 \mathrm{~m})$ was recorded with an Aandera salinity-temperature probe, with sampling frequencies ranging from 0.3 to $12 \mathrm{~d}^{-1}$. Rainfall data were obtained from a meteorological station located $500 \mathrm{~m}$ from the sampling site. Complementary data on rainfall were obtained from 2 additional meteorological stations within the watershed of the Tordera River.

At the laboratory, $500 \mathrm{ml}$ was filtered through a Whatman GF/F filter for fluorometric analysis of chl a concentration (Parsons et al. 1984). The filters were homogenized and kept refrigerated in the dark while pigments were extracted in $90 \%$ acetone for ca $6 \mathrm{~h}$. Fluorescence was then measured in a Turner Designs fluorometer calibrated with pure chl a (Sigma Co.).

Bacterioplankton and heterotrophic nanoflagellate abundances were determined by epifluorescence microscopy (Porter \& Feig 1980). Duplicate subsamples of 5 to $10 \mathrm{ml}$ (bacterioplankton) and 20 to $30 \mathrm{ml}$ (hetero-

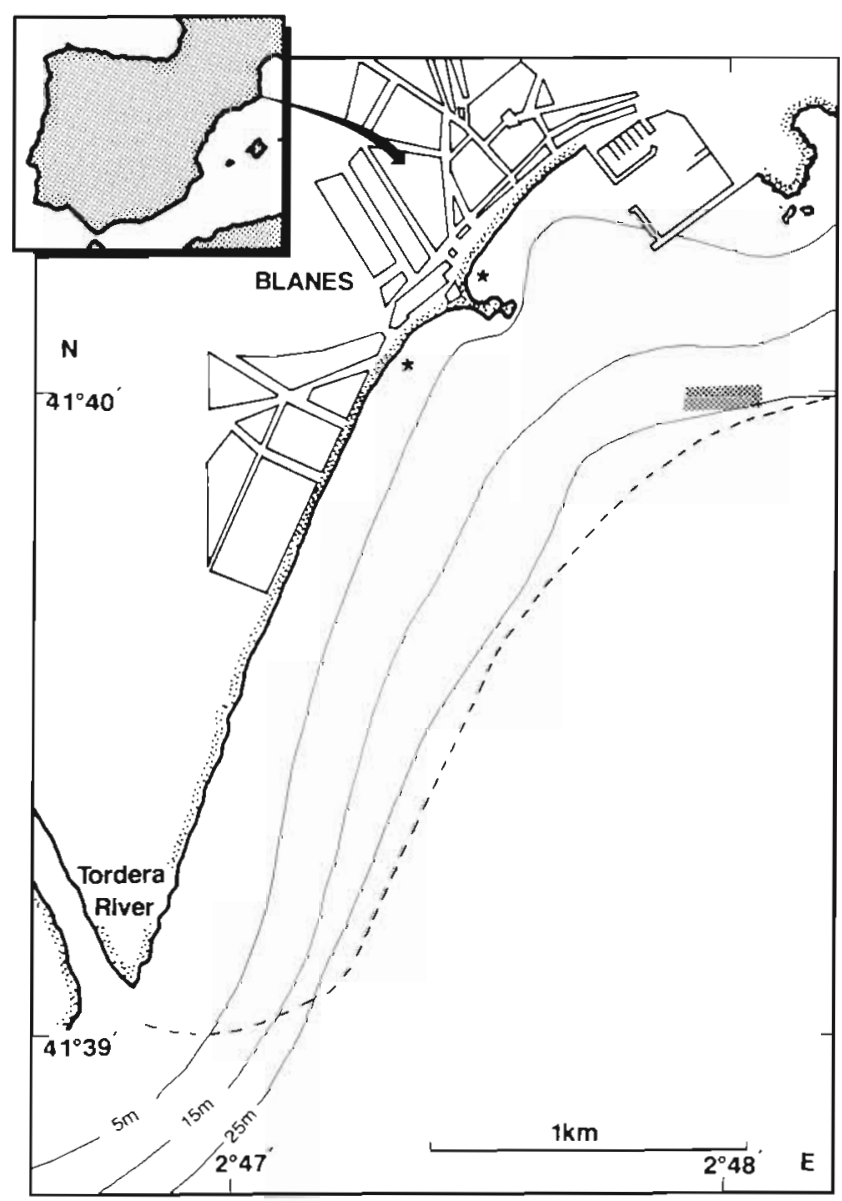

Fig. 1. Map of study area (Bay of Blanes, NW Mediterranean Sea). Shaded area: sampling site $_{i}(*)$ point of intermittent water discharge; (- ) water discharge from Tordera River 
trophic nanoflagellates) were stained with DAPI and filtered through $0.2 \mu \mathrm{m}$ and $0.6 \mu \mathrm{m}$ to collect bacterioplankton and heterotrophic nanoflagellates, respectively. Error between duplicates ranged from 5 to $20 \%$. Data on heterotrophic nanoflagellates covered the period from March 1992 to February 1994.

Ciliate abundance was examined in single $100 \mathrm{ml}$ samples, which were preserved in a $1 \%$ final concentration of acidic Lugol's solution, and sedimented in $100 \mathrm{ml}$ chambers for at least $48 \mathrm{~h}$ before enumeration, at $200 \times$ or $400 \times$ magnification, using an inverted microscope. Ciliate cells were determined to genus, when possible, following Lee et al. (1985) and Aladro Lubel et al. (1990). Taxa were placed into groups as 'oligotrichs' which included some genera considered heterotrophic, e.g. Halteria, Strombidium, Strobilidium, and Lohmaniella, and large mixotrophic genera, Laboea and Tontonia. We considered loricate tintinnids separately, and empty lorica were not enumerated. Other ciliate taxa were pooled by order: Haptorida which included mainly Mesodinium although in a few $(<1 \%)$ cases Askenasia was present. Other orders present in the samples were Scuticociliatida (mainly Cyclidium and Uronema), Pleuroestomatida (Amphyleptus) and Prorodontida (Urotricha). Ciliate biomass was estimated as ciliate biovolume, which was calculated by approximation to the nearest geometric shape from measurements of cell length and width of at least 20 ciliate cells per sample. To avoid the probable underestimation of ciliate biovolume due to fixation with Lugol's solution (Leakey et al. 1994, Stoecker et al. 1994), the average cell volume for each genus was converted to carbon equivalents using the factor experimentally derived for Lugol'sfixed marine oligotrichs, $0.2 \mathrm{pg} \mathrm{C} \mathrm{m}^{-3}$ (Putt \& Stoecker 1989), except for tintinnid carbon, which was estimated using the experimentally derived factor of $0.053 \mathrm{pg} \mathrm{C} \mathrm{mm}^{-3}$ lorica volume (Verity \& Langdon 1984).

The relationship between temperature and biological variables was examined by means of Pearson's correlation analysis, and the differences in biological properties between rainy and dry periods were tested by ANOVA. Cross correlation analyses were used to test the relationship between ciliate abundance and other components of microbial food webs.

The structure of the temporal variability observed in the Bay of Blanes was examined by first quantifying, using ANOVA, the significance of the variance at difference scales of variation. We then identified the dominant time scales of variation. Semivariance (S-V) at the time scale $t$ (days) was calculated according to the equation (Robertson 1987):

$$
S-V(t)=(1 / 2 n)\left(c_{x}-c_{x}+t\right)^{2}
$$

where $c_{x}$ is ciliate abundance at time $x, n$ is the number of observations for each time difference, and $t$ is the time elapsed between $C_{x}$ and $c_{x+t}$ (i.e. the time scale evaluated). In practice, $S-V$ is calculated for lag times up to half the length of the total record, which is the largest time scale that can be resolved with the analysis (Robertson 1987). The shape of the semivariogram typically shows an increase in S-V with increasing time scale up to a plateau (i.e. sill value; Robertson 1987), which indicates the dominant time scale in the process examined. Semivariogram analysis is particularly well suited to investigating the dynamic behavior of time series sampled with different intensity, such as the ciliate abundance and biomass reported here, which were sampled once or twice per week, or daily during the study.

\section{RESULTS}

\section{Relationship between environmental and biological variables}

Surface water temperature fluctuated from minimal values of 11 to $12^{\circ} \mathrm{C}$ in late January and February, to maximal values of 25 to $26^{\circ} \mathrm{C}$ in late August and September (Fig. 2a). Despite the strong temperature seasonality, chl a concentration did not show a simple seasonal pattern (Fig. 3a). The pattern was highly variable among years, however a distinct winter and summer bloom of phytoplankton was present in each year, concurrent with winter minimum and summer maximum temperatures (Figs. 2a \& 3a), despite an overall negative correlation between surface temperature and chl a concentration $(r=-0.442, p=0.007)$. The abundance of microheterotrophs (bacteria, heterotrophic nanoflagellates, and ciliates) fluctuated greatly throughout the study period (Figs. 3b, c \& 4), independently of temperature (Fig. 2a).

Examination of the cumulative monthly rainfall (Fig. $2 b$ ) shows that periods of heavy rainfall $\left(>20 \mathrm{l} \mathrm{m}^{-2}\right.$ $\mathrm{d}^{-1}$ ), sufficient to cause torrential river discharge, were more frequent and more intense in 1992 compared with the following years, with the period 1993-1994 being particularly dry, except for October 1994 (Table 1, Fig. 2b). The heaviest rainfall was recorded in spring 1992, when storms discharged $44 \mathrm{l} \mathrm{m}^{-2}$ in a few hours in June, and in October 1994, when $61 \mathrm{l} \mathrm{m}^{-2}$ were discharged in a short period (Fig. 2b).

The comparison of changes in microheterotroph abundance and chl a concentration during periods of heavy rainfall showed a significant increase in the abundance of bacteria and heterotrophic nanoflagellates during heavy rain periods (Table 2). Hence, increased bacteria and heterotrophic nanoflagellate 

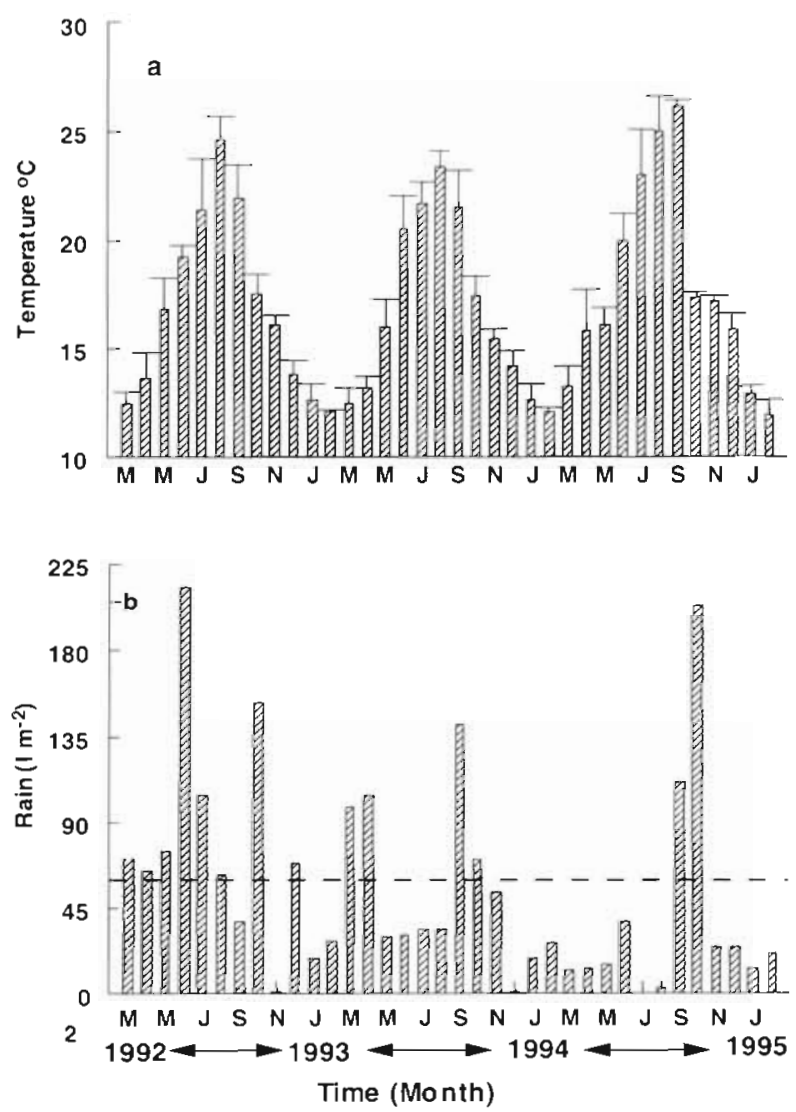

Fig. 2. (a) Average of monthly values of temperature (bars indicate standard deviation) and (b) cumulative monthly rainfall values. Dashed line refers to values of cumulative monthly rainfall greater than $50 \mathrm{l} \mathrm{m}^{-2}$

abundance was observed in spring and summer 1992, and in autumn 1994 for bacterial abundance, and in spring 1992 for heterotrophic nanoflagellates (Table 2). In contrast, ciliate abundance tended to decline during periods of heavy rain (Table 2). This effect was particularly evident during spring 1992 (Table 2, Figs. 2b \& 4 a). The decline in ciliate abundance during periods of heavy rain was mainly due to a decline in heterotrophic oligotrichs $(p<0.05$ and $p<0.018$ for abundance and biomass, respectively) and Mesodinium ( $p<0.013$ for biomass).

\section{Chl a concentration, bacterial and heterotrophic nanoflagellate abundance}

Chl a concentration over the study period ranged from $0.010 \mu \mathrm{g} \mathrm{l}^{-1}$ in August 1994 to $5.75 \mu \mathrm{g} \mathrm{l}^{-1}$ in March 1992. Maximum values for 1993 and 1994 were recorded in February $\left(2.74 \mathrm{\mu g} \mathrm{I}^{-1}\right)$ and January $(5.01 \mu \mathrm{g}$ $\left.1^{-1}\right)$, respectively. These phytoplankton blooms in winter are a consistent feature of the Catalan coast. Bacterial abundance values ranged from $0.5 \times 10^{5}$ cells $\mathrm{ml}^{-1}$
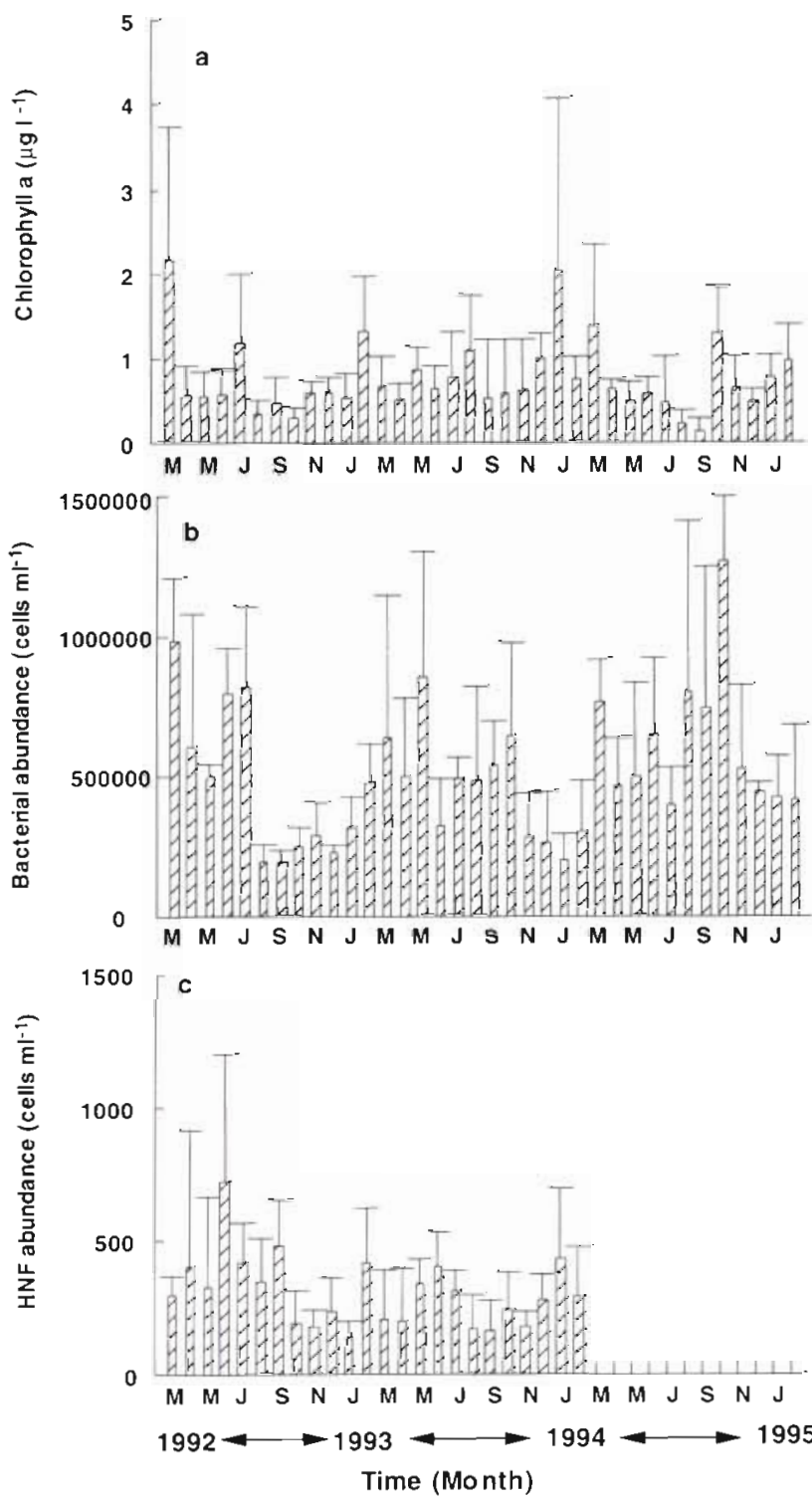

Fig. 3. Monthly average of (a) chlorophyll a concentration and (b) bacterial and (c) heterotrophic (HNF) nanoflagellate abundance (bars indicate standard deviation)

in August 1993 to $18.7 \times 10^{5}$ cells $\mathrm{ml}^{-1}$ in August 1994 . The peak bacterial abundances for 1992 and 1993 were both observed in March $\left(14.4 \times 10^{5}\right.$ and $14.9 \times$ $10^{5}$ cells $\mathrm{ml}^{-1}$, respectively). Finally, the abundance of heterotrophic nanoflagellates ranged from 20 cells $\mathrm{ml}^{-1}$ in September 1993 to $1.7 \times 10^{3}$ cells $\mathrm{ml}^{-1}$ in June 1992, with the maximum values for $1993(0.79 \times$ $10^{3}$ cells $\mathrm{ml}^{-1}$ ) being recorded in February. The monthly mean chl a concentration and bacterial abundance showed similar trends (Fig. 3), with chl a blooms being followed by increased bacterial abundance. In contrast, the monthly mean abundance of heterotrophic nanoflagellates was low when mean bacterial abundance was high (Fig. 3). 
Table 1. Seasonal rain frequency (\%) in the study period

\begin{tabular}{|lcrrrr|}
\hline Year & $\begin{array}{c}\text { Rainfall } \\
\text { (range) }\left(1 \mathrm{~m}^{-2}\right)\end{array}$ & Spring & Summer & Autumn & Winter \\
\hline $1992-1993$ & $>20$ & 6.59 & 4.35 & 3.33 & 2.24 \\
& $10-20$ & 5.49 & 4.35 & 3.33 & 7.86 \\
& $5-10$ & 9.89 & 2.17 & 6.67 & 4.49 \\
& $0.01-5$ & 21.86 & 16.00 & 23.3 & 13.48 \\
& 0 & 56.17 & 73.13 & 63.37 & 71.93 \\
$1993-1994$ & $>20$ & 1.08 & 0.00 & 3.33 & 0.00 \\
& $10-20$ & 4.35 & 2.19 & 5.55 & 3.30 \\
& $5-10$ & 7.61 & 5.49 & 4.44 & 1.12 \\
& $0.01-5$ & 15.2 & 19.78 & 44.44 & 8.98 \\
$1994-1995$ & 0 & 71.76 & 72.54 & 42.24 & 86.60 \\
& $>20$ & 0.00 & 2.22 & 5.49 & 0.00 \\
& $10-20$ & 1.09 & 2.22 & 4.39 & 1.47 \\
& $5-10$ & 0.00 & 0.00 & 3.30 & 0.00 \\
& $0.01-5$ & 16.48 & 10.00 & 16.48 & 17.65 \\
& 0 & 82.43 & 85.56 & 70.34 & 80.88 \\
\hline
\end{tabular}

Table 2. Differences in bacterial and heterotrophic nanoflagellate abundance (BN and HNF: cells $\mathrm{ml}^{-1}$ ), chlorophyll a concentration (chl $a: \mu \mathrm{g} \mathrm{l}^{-1}$ ),

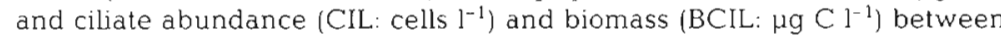
rain vs no rain periods performed by means of a multifactorial ANOVA ( $p<$ 0.05 , marginally significant; ns: not significant; nd: not determined). Positive $(+)$ and negative $(-)$ symbols indicate values were higher during heavy rain periods $\left(>10 \mathrm{l} \mathrm{m}^{-2}\right)$ or lower with respect to no rain periods, respectively

\begin{tabular}{|llclllc|}
\hline Year & Season & BN & HNF & Chl a & CIL & BCIL \\
\hline All & Pooled & $0.001(+)$ & $0.02(+)$ & ns & $0.05(-)$ & ns \\
1992 & Pooled & $0.014(+)$ & $0.08^{\circ}(+)$ & ns & ns & ns \\
1993 & Pooled & ns & ns & ns & ns & ns \\
1994 & Pooled & $0.066^{\circ}(+)$ & nd & ns & ns & ns \\
1992 & Spring & $0.031(+)$ & $0.05(+)$ & n.s & $0.045(-)$ & $0.018(-)$ \\
& Summer & $0.013(+)$ & ns & ns & ns & ns \\
1994 & Autumn & $0.028(+)$ & nd & $0.03(+)$ & ns & ns \\
\hline
\end{tabular}

\section{Ciliate abundance and biomass}

Total ciliate abundance averaged 3851 cells $\mathrm{l}^{-1}$ over the 3 yr period, ranging from

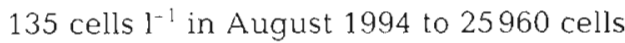
$\mathrm{I}^{-1}$ in March 1994 (Table 3). Oligotrichs were the most important group. Heterotrophic oligotrichs (Halteria, Strombidium, Strobilidium and Lohmaniella) dominated the ciliate community with an average abundance of 1884 cells $\mathrm{I}^{-1}$. Mixotrophic oligotrichs (Laboea and Tontonia) were less abundant (mean

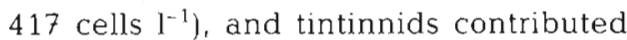
an average abundance of 629 cells $1^{-1}$. Oligotrichs were consistently present throughout the entire study period. The peak abundance of mixotrophic oligotrichs and tintinnids occurred simultaneously with the maximum abundance of the ciliate community (Table 3). In the third year of this study, however, the abundance of oligotrichs was exceeded by that of loricate ciliates, due to a remarkable increase in tintinnid abundance. Interestingly, this tintinnid bloom did not suffice to overcome oligotrich dominance of ciliate biomass (Table 3 ). The autotrophic Mesodinium (order Haptorida) was also an important contributor to ciliate abundance, with an average density of 499 cells $\mathrm{l}^{-1}$. Other orders contributing to the ciliate community, listed from maximum to minimum abun-

Table 3. Mean, maximum and minimum values of ciliate abundance (cell $\mathrm{l}^{-1}$ ) and biomass ( $\mu \mathrm{gg} \mathrm{Cl}^{-1}$ ) in the $\mathrm{Bay}$ of $\mathrm{Blanes}$ ( $\mathrm{NW}$ Mediterranean) from March 1992 to March 1995, and the percent contribution (\%) of each ciliate group

\begin{tabular}{|c|c|c|c|c|c|c|c|c|}
\hline Group & Variable & Mean & Max. & Min. & $\begin{array}{l}\text { Percent } \\
\text { overall }\end{array}$ & $\begin{array}{l}\text { Percent } \\
\text { Year } 1\end{array}$ & $\begin{array}{l}\text { Percent } \\
\text { Year } 2\end{array}$ & $\begin{array}{l}\text { Percent } \\
\text { Year } 3\end{array}$ \\
\hline $\begin{array}{l}\text { Total ciliate } \\
\text { community }\end{array}$ & $\begin{array}{l}\text { Abundance } \\
\text { Biomass }\end{array}$ & $\begin{array}{l}3851 \\
5.37\end{array}$ & $\begin{array}{r}25960(\text { Mar 94) } \\
96.27(\text { Mar 94) }\end{array}$ & $\begin{array}{c}135 \\
0.031\end{array}$ & & & & \\
\hline Heterotrophic oligotrichs & $\begin{array}{l}\text { Abundance } \\
\text { Biomass }\end{array}$ & $\begin{array}{l}1884 \\
1.66\end{array}$ & $\begin{array}{l}11202(\text { Nov } 94) \\
27.13(\text { Mar } 94)\end{array}$ & $\begin{array}{l}0.0 \\
0.0\end{array}$ & $\begin{array}{l}50 \\
41\end{array}$ & $\begin{array}{l}55 \\
33\end{array}$ & $\begin{array}{l}61 \\
47\end{array}$ & $\begin{array}{l}29 \\
50\end{array}$ \\
\hline Mixotrophic oligotrichs & $\begin{array}{l}\text { Abundance } \\
\text { Biomass }\end{array}$ & $\begin{array}{l}417 \\
1.02\end{array}$ & $\begin{array}{r}8923 \text { (Mar 94) } \\
52.28(\text { Mar 94) }\end{array}$ & $\begin{array}{l}0.0 \\
0.0\end{array}$ & $\begin{array}{l}11 \\
17\end{array}$ & $\begin{array}{l}13 \\
17\end{array}$ & $\begin{array}{r}9 \\
16\end{array}$ & $\begin{array}{r}7 \\
17\end{array}$ \\
\hline Tintinnids & $\begin{array}{l}\text { Abundance } \\
\text { Biomass }\end{array}$ & $\begin{array}{l}629 \\
0.28\end{array}$ & $\begin{array}{r}7436(\text { Mar 94) } \\
10.15 \text { (Mar 93) }\end{array}$ & $\begin{array}{l}0.0 \\
0.0\end{array}$ & $\begin{array}{r}16 \\
7\end{array}$ & $\begin{array}{l}7 \\
7\end{array}$ & $\begin{array}{l}7 \\
3\end{array}$ & $\begin{array}{l}41 \\
13\end{array}$ \\
\hline Mesodinium & $\begin{array}{l}\text { Abundance } \\
\text { Biomass }\end{array}$ & $\begin{array}{l}499 \\
0.44\end{array}$ & $\begin{array}{c}4272 \text { (May 92) } \\
14.53(\text { Mar 94) }\end{array}$ & $\begin{array}{l}0.0 \\
0.0\end{array}$ & $\begin{array}{l}11 \\
11\end{array}$ & $\begin{array}{r}10 \\
7\end{array}$ & $\begin{array}{l}13 \\
15\end{array}$ & $\begin{array}{l}13 \\
16\end{array}$ \\
\hline Scuticociliatida & $\begin{array}{l}\text { Abundance } \\
\text { Biomass }\end{array}$ & $\begin{array}{l}236 \\
0.62\end{array}$ & $\begin{array}{l}2974 \text { (Jun 94) } \\
19.49 \text { (Jun 93) }\end{array}$ & $\begin{array}{l}0.0 \\
0.0\end{array}$ & $\begin{array}{r}8 \\
12\end{array}$ & $\begin{array}{r}7 \\
15\end{array}$ & $\begin{array}{r}8 \\
15\end{array}$ & $\begin{array}{l}9 \\
3\end{array}$ \\
\hline Pleurostomatida & $\begin{array}{l}\text { Abundance } \\
\text { Biomass }\end{array}$ & $\begin{array}{c}71 \\
0.51\end{array}$ & $\begin{array}{r}1984 \text { (Jul 92) } \\
42.95 \text { (Jul 92) }\end{array}$ & $\begin{array}{l}0.0 \\
0.0\end{array}$ & $\begin{array}{l}2 \\
6\end{array}$ & $\begin{array}{r}4 \\
12\end{array}$ & $\begin{array}{l}1 \\
2\end{array}$ & $\begin{array}{l}<1 \\
<1\end{array}$ \\
\hline Prorodontida & $\begin{array}{l}\text { Abundance } \\
\text { Biomass }\end{array}$ & $\begin{array}{c}9 \\
0.04\end{array}$ & $\begin{array}{r}657 \text { (Mar 93) } \\
3.60 \text { (Mar 93) }\end{array}$ & $\begin{array}{l}0.0 \\
0.0\end{array}$ & $\begin{array}{r}<1 \\
1\end{array}$ & $\begin{array}{r}<1 \\
1\end{array}$ & $\begin{array}{l}<1 \\
<1\end{array}$ & $\begin{array}{l}<1 \\
<1\end{array}$ \\
\hline
\end{tabular}



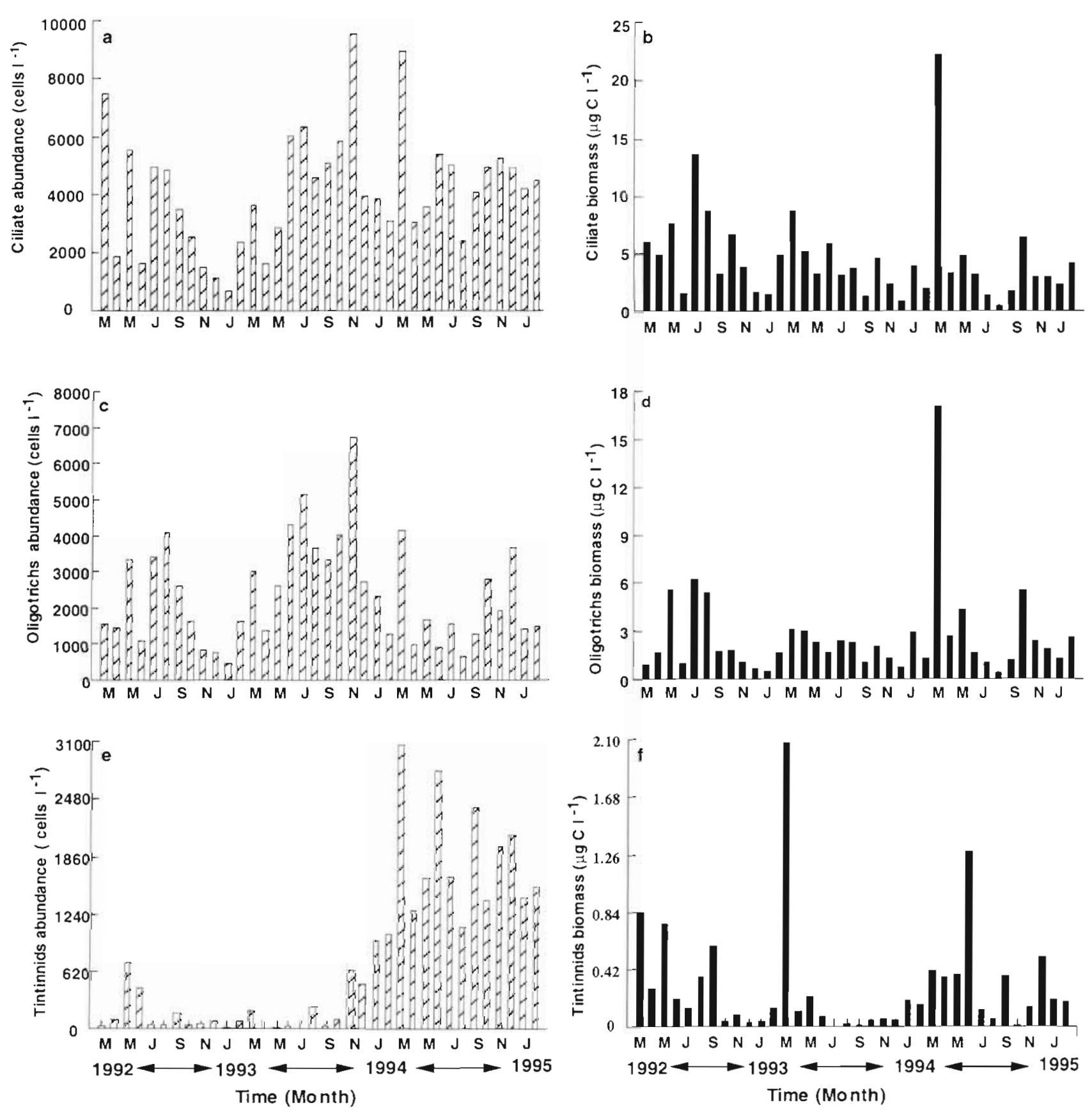

Fig. 4. Monthly averages of (a) ciliate community abundance (coefficient of variation, CV: 18 to $137 \%$ ) and (b) biomass (CV: 11 to $198 \%$ ), (c) oligotrich (heterotrophic plus mixotrophic) abundance (CV: 13 to $151 \%$ ) and (d) biomass (CV: 14 to $205 \%$ ), and (e) tintinnids abundance (CV: 36 to $224 \%$ ) and (f) biomass (CV: 30 to $264 \%$ )

dance, included Scuticociliatida (Uronema and Cyclidium), Pleurostomatida (Amphyleptus) and Prorodontida (Urotricha). The maximum abundance of these forms was independent of that of the total ciliate community (Table 3). The biomass of the ciliate community averaged $5.37 \mu \mathrm{C} \mathrm{Cl}^{-1}$, reaching the highest value in March 1994, and was dominated by oligotrichs (Table 3).

\section{Seasonal variation of ciliate abundance and biomass}

Ciliate abundance was highly variable on both a seasonal and a monthly time scale (Figs. $4 \& 5$ ). The coefficient of variation of the monthly ciliate abundance ranged from 18 to $137 \%$ and that for ciliate biomass ranged from 11 to $198 \%$. This variability was even higher when for individual ciliate groups. In the first 

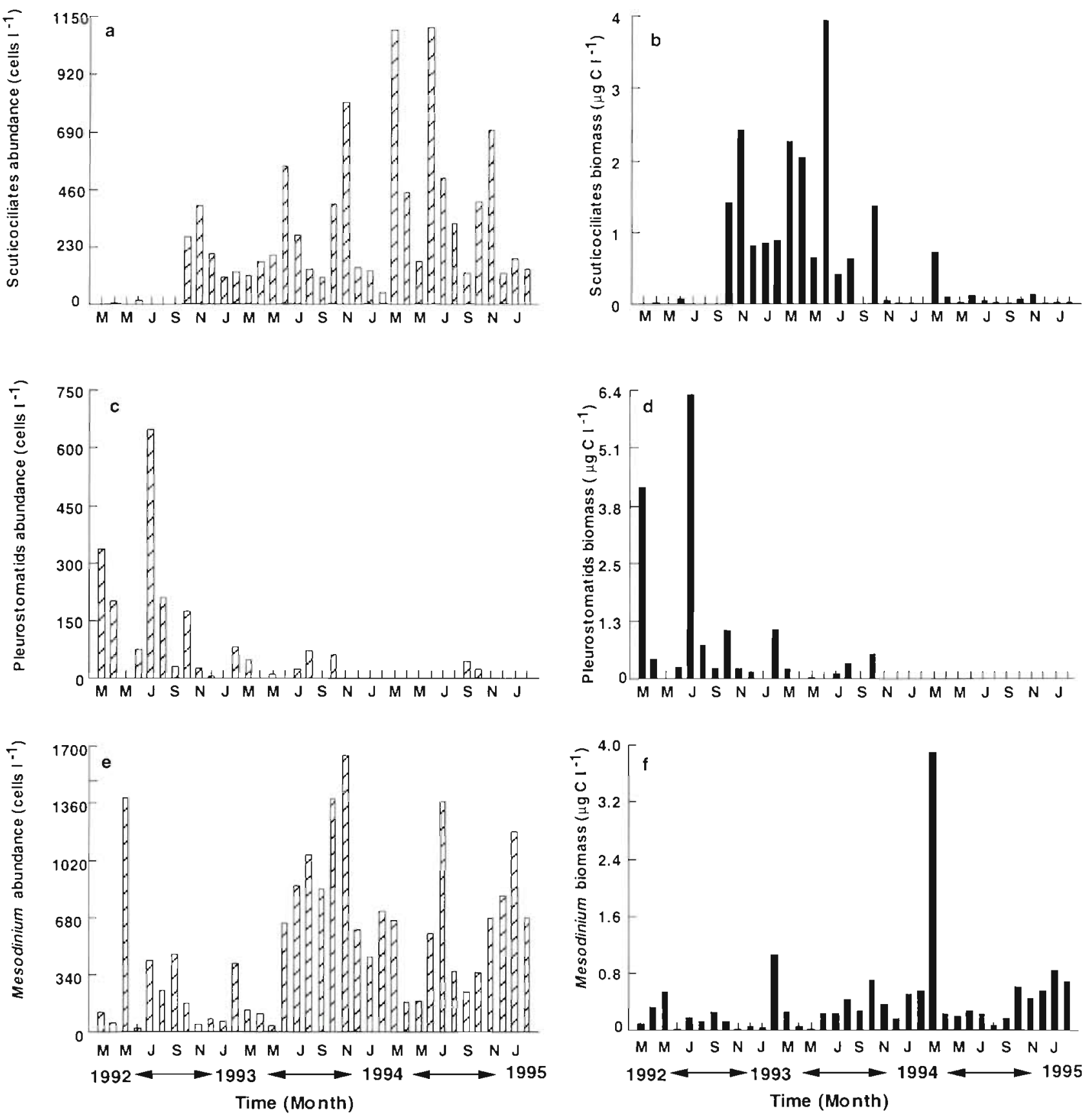

Fig. 5. Monthly average of (a) Scuticociliatida abundance (CV: 44 to $283 \%$ ) and (b) biomass (CV: 55 to $283 \%$ ), (c) Pleurostomatida abundance (CV: 71 to $245 \%$ ) and (d) biomass (CV: 97 to 245\%), and (e) Mesodinium abundance (CV: 26 to $204 \%$ ) and (f) biomass (CV: 37 to $259 \%$ )

and second years total ciliate abundance showed a late spring bloom, summer bloom, and additional blooms in the fall of the second and third years, after the phytoplankton blooms and increases of bacterial abundances (Figs. 3 \& 4a). Cross correlation analysis revealed that bacterial abundance and chl a concentration were both significantly negatively correlated with ciliate abundance, with a time lag of about 2 wk $(p<0.05)$.
Total ciliate biomass peaked in late winter/early spring and in the fall of every year, while an additional summer peak was observed in the first year (Fig. 4b).

Oligotrich abundance and biomass (heterotrophic and mixotrophic) followed those of the ciliate community (Fig. 4c, d). Tintinnids showed a small spring bloom in the first year followed by a decline in abundance throughout the remaining seasons. There was 
considerable seasonal variability in the second and third year, with a small summer peak, followed by a greater peak in the fall of the second year, and peak tintinnid abundance in late winter/early spring, tollowed by several peaks in late spring, summer, and fall of the third year (Fig. 4e). Tintinnid biomass was characterized by maxima in late winter/early spring for 1992 and 1993, the first and third year showed secondary peaks at the end of the summer (September). and a small winter peak in the third year (Fig. 4f).

The relative contribution of heterotrophic oligotrichs to total oligotrich abundance was highest in 1992 to 1994 (58 to $98 \%$ ), while tintinnids were the most important components ( 40 to $78 \%$ ) of the heterotrophic oligotrichs (naked and loricate) from 1994 to 1995 (Fig. 6a). The contribution of mixotrophic oligotrichs to the oligotrich community was substantially lower than that of heterotrophic oligotrichs (Fig. 6a). However, large mixotrophic oligotrichs contributed a high percentage of the total oligotrich biomass in spring and/or summer over the study period (Fig. 6b).

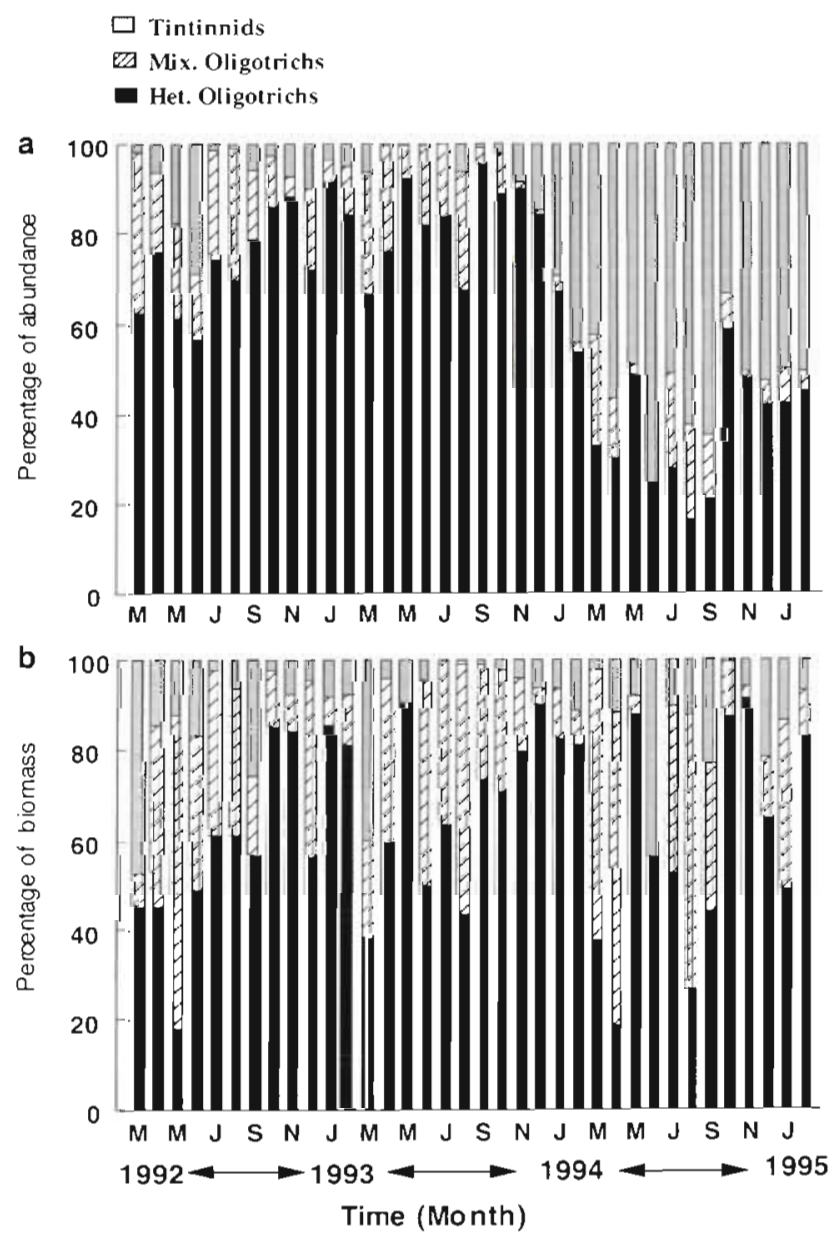

Fig. 6. Relative contribution of naked heterotrophic, mixotrophic, and tintinnid (a) abundance to total oligotrich abundance and (b) biomass to total oligotrich biomass
The abundance and biomass of Scuticociliatida and Pleurostomatida were lower than those of oligotrichs. Scuticociliatida showed persistent blooms in the fall of every year, with substantial summer blooms recorded in the second and third years, when a significant bloom occurred in late winter/early spring as well (Fig. 5a). The biomass of Scuticociliatida showed a significant peak in the fall of the first and second years, and blooms in late winter/early spring in the second and third years (Fig. 5b). The order Pleurostomatida produced blooms in late winter/early spring, summer, with its abundance being substantially greater in the first year (Fig. 5c). Biomass did not reflect significant seasonal variation within the second or third year, except for a small peak in the fall of the second year. Three peaks were detected in the first year, including a late winter/early spring peak, a large summer peak (coinciding with that of total ciliate biomass for this year), and an additional autumn peak, also recorded in the second year (Fig 5d). The order Prorodontida presented very low abundance and biomass during the whole period.

The seasonal pattern of the autotrophic Mesodinium varied greatly among years. In the first year Mesodinium sp. produced a strong bloom later in the spring and 2 smaller blooms in the summer. In contrast, the second year was characterized by a substantial summer peak, followed by an even greater autumn bloom, and blooms occurred in late winter/early spring, summer and mid-winter of the third year (Fig. 5e). With respect to biomass, the first year seasonal pattern was characterized by a small peak later in the spring. A late winter/early spring peak, together with an smaller autumn peak, was observed in the second and third years. The large biomass peak observed in the spring of the third year coincided with that of the oligotrich and total ciliate biomass (Fig. 5f).

The abundance and biomass of Mesodinium were not directly correlated with chl a concentration, despite the autotrophic nature of Mesodinium. However, the abundance and biomass of Mesodinium were significantly correlated with chl $a$ at seasonal scales (Figs. 3a \& 5e, f). These positive correlations were observed in winter $1993\left(\mathrm{r}_{\mathrm{abundance}}=0.509, \mathrm{p}<0.031\right.$ and $\mathrm{r}_{\text {biomass }}=0.576, \mathrm{p}<0.012$, respectively) and in summer 1994 ( $\mathrm{r}_{\text {bomass }}=0.599, \mathrm{p}<0.05$ ).

\section{Interannual variability in ciliate abundance and biomass}

The preceding description of seasonal patterns provides indication of major interannual differences in the abundance and biomass of ciliates over the study period (Tables $4 \& 5$ ). The abundance of ciliates dif- 
Table 4. Mean annual values of ciliate abundance (cells $\left.\mathrm{l}^{-1}\right)$, biomass $\left(\mu \mathrm{g} \mathrm{Cl}^{-1}\right)$ and biomass ciliate ${ }^{-1}$ (ng $\mathrm{C}$ cell $^{-1}$ ). $\mathrm{CV} \cdot \mathrm{coeffi}^{-}$ cient of variation for each variable

\begin{tabular}{|c|c|c|c|c|c|c|c|}
\hline Variable & Year & Abund. & $\mathrm{CV}$ & Biomass & $\mathrm{CV}$ & Biom./cil. & $\mathrm{CV}$ \\
\hline Ciliate community & $\begin{array}{l}1992-1993 \\
1993-1994 \\
1994-1995\end{array}$ & $\begin{array}{l}2833 \\
4679 \\
4759\end{array}$ & $\begin{array}{l}90 \\
74 \\
80\end{array}$ & $\begin{array}{l}6.35 \\
4.02 \\
4.98\end{array}$ & $\begin{array}{l}168 \\
150 \\
270\end{array}$ & $\begin{array}{l}2.35 \\
1.22 \\
0.72\end{array}$ & $\begin{array}{r}108 \\
132 \\
90\end{array}$ \\
\hline Heterotrophic oligotrichs & $\begin{array}{l}1992-1993 \\
1993-1994 \\
1994-1995\end{array}$ & $\begin{array}{l}1576 \\
2950 \\
1334\end{array}$ & $\begin{array}{r}105 \\
81 \\
86\end{array}$ & $\begin{array}{l}1.54 \\
1.39 \\
2.17\end{array}$ & $\begin{array}{l}140 \\
117 \\
193\end{array}$ & $\begin{array}{l}0.97 \\
0.60 \\
1.21\end{array}$ & $\begin{array}{l}86 \\
81 \\
82\end{array}$ \\
\hline Mixotrophic oligotrichs & $\begin{array}{r}1992-1993 \\
1993-1994 \\
1994-1995\end{array}$ & $\begin{array}{l}411 \\
426 \\
425\end{array}$ & $\begin{array}{l}163 \\
164 \\
297\end{array}$ & $\begin{array}{l}1.00 \\
0.62 \\
1.50\end{array}$ & $\begin{array}{l}196 \\
162 \\
492\end{array}$ & $\begin{array}{l}2.29 \\
1.93 \\
1.89\end{array}$ & $\begin{array}{r}102 \\
86 \\
111\end{array}$ \\
\hline Tintinnids & $\begin{array}{l}1992-1993 \\
1993-1994 \\
1994-1995\end{array}$ & $\begin{array}{r}157 \\
282 \\
1875\end{array}$ & $\begin{array}{r}240 \\
164 \\
77\end{array}$ & $\begin{array}{l}0.24 \\
0.27 \\
0.35\end{array}$ & $\begin{array}{l}297 \\
511 \\
192\end{array}$ & $\begin{array}{l}2.86 \\
2.13 \\
0.17\end{array}$ & $\begin{array}{l}208 \\
230 \\
120\end{array}$ \\
\hline Mesodinium & $\begin{array}{l}1992-1993 \\
1993-1994 \\
1994-1995\end{array}$ & $\begin{array}{l}317 \\
713 \\
616\end{array}$ & $\begin{array}{l}211 \\
122 \\
119\end{array}$ & $\begin{array}{l}0.30 \\
0.34 \\
0.79\end{array}$ & $\begin{array}{l}247 \\
122 \\
277\end{array}$ & $\begin{array}{l}1.21 \\
0.71 \\
1.12\end{array}$ & $\begin{array}{l}138 \\
132 \\
143\end{array}$ \\
\hline Scuticociliatida & $\begin{array}{l}1992-1993 \\
1993-1994 \\
1994-1995\end{array}$ & $\begin{array}{r}99 \\
271 \\
454\end{array}$ & $\begin{array}{l}261 \\
131 \\
129\end{array}$ & $\begin{array}{l}0.59 \\
1.15 \\
0.13\end{array}$ & $\begin{array}{l}226 \\
275 \\
233\end{array}$ & $\begin{array}{l}7.86 \\
4.64 \\
0.27\end{array}$ & $\begin{array}{l}106 \\
162 \\
166\end{array}$ \\
\hline Pleurostomatida & $\begin{array}{l}1992-1993 \\
1993-1994 \\
1994-1995\end{array}$ & $\begin{array}{r}137 \\
20 \\
5\end{array}$ & $\begin{array}{l}226 \\
367 \\
523\end{array}$ & $\begin{array}{l}1.00 \\
0.12 \\
0.001\end{array}$ & $\begin{array}{l}449 \\
416 \\
547\end{array}$ & $\begin{array}{l}7.86 \\
5.20 \\
0.14\end{array}$ & $\begin{array}{l}99 \\
37 \\
22\end{array}$ \\
\hline
\end{tabular}

fered significantly (Tukey multiple comparison test, $\mathrm{p}<$ 0.05 ) in the first year with respect to the following 2 years, when mean annual abundance was lowest and cell size largest ( $p<0.01$, Tables $4 \& 5$ ). The abundance of naked heterotrophic oligotrichs differed significantly in the second year with respect to the first and third years, when the maximum mean density was observed $\left(\right.$ mean $=2950$ cells $1^{-1}$; Table 4$)$. The abundance of tintinnids increased remarkably over the third year. The abundance of Mesodinium and Pleurostomatida was significantly different in the first year from the other years, whereas Scuticociliatida showed great

Table 5. Comparison (Tukey HSD test) of the abundance (cells $\mathrm{l}^{-1}$ ), biomass ( $\mu \mathrm{g} \mathrm{Cl}^{-1}$ ) and biomass ciliate ${ }^{-1}$ (ng C celli ${ }^{-1}$ ) of each ciliate group among years, and ANOVA test of the significance of interannual differences in abundance and biovolume for the 3 yr period (1992 to 1995). "Marginally significant; ns: not significant

\begin{tabular}{|c|c|c|c|c|c|}
\hline Group & Variable & Year $1-2$ & Year 2-3 & Year $1-3$ & Total \\
\hline Total ciliate & $\begin{array}{l}\text { Abundance } \\
\text { Biomass } \\
\text { Biomass/ciliate }\end{array}$ & $\begin{array}{c}0.001 \\
\text { ns } \\
0.001\end{array}$ & $\begin{array}{l}\text { ns } \\
\text { ns } \\
\text { ns }\end{array}$ & $\begin{array}{c}0.001 \\
\mathrm{~ns} \\
<0.0001\end{array}$ & $\begin{array}{c}<0.0001 \\
\text { ns } \\
<0.0001\end{array}$ \\
\hline Heterotrophic oligotrichs & $\begin{array}{l}\text { Abundance } \\
\text { Biomass } \\
\text { Biomass/ciliate }\end{array}$ & $\begin{array}{c}<0.0001 \\
\text { ns } \\
0.01\end{array}$ & $\begin{array}{c}<0.0001 \\
\text { ns } \\
<0.0001\end{array}$ & $\begin{array}{l}\mathrm{ns} \\
\mathrm{ns} \\
0.081\end{array}$ & $\begin{array}{c}<0.0001 \\
\text { ns } \\
0.001\end{array}$ \\
\hline Mixotrophic oligotrichs & $\begin{array}{l}\text { Abundance } \\
\text { Biomass } \\
\text { Biomass/ciliate }\end{array}$ & $\begin{array}{l}\text { ns } \\
\text { ns } \\
\text { ns }\end{array}$ & $\begin{array}{l}\text { ns } \\
\text { ns } \\
\text { ns }\end{array}$ & $\begin{array}{l}\text { ns } \\
\text { ns } \\
\text { ns }\end{array}$ & $\begin{array}{l}\text { ns } \\
\text { ns } \\
\text { ns }\end{array}$ \\
\hline Tintinnids & $\begin{array}{l}\text { Abundance } \\
\text { Biomass } \\
\text { Biomass/ciliate }\end{array}$ & $\begin{array}{l}\text { ns } \\
\text { ns } \\
\text { ns }\end{array}$ & $\begin{array}{c}<0.0001 \\
\text { ns } \\
0.060^{\circ}\end{array}$ & $\begin{array}{c}<0.0001 \\
\text { ns } \\
0.003\end{array}$ & $\begin{array}{c}<0.0001 \\
\text { ns } \\
0.009\end{array}$ \\
\hline Mesodinium & $\begin{array}{l}\text { Abundance } \\
\text { Biomass } \\
\text { Biomass/ciliate }\end{array}$ & $\begin{array}{l}0.002 \\
\text { ns } \\
0.091 .\end{array}$ & $\begin{array}{l}\text { ns } \\
0.067 \\
\text { ns }\end{array}$ & $\begin{array}{c}0.023 \\
0.026 \\
\text { ns }\end{array}$ & $\begin{array}{l}0.004 \\
0.067 \\
\text { ns }\end{array}$ \\
\hline Scuticociliatida & $\begin{array}{l}\text { Abundance } \\
\text { Biomass } \\
\text { Biomass/ciliate }\end{array}$ & $\begin{array}{l}0.012 \\
0.084 \\
0.030\end{array}$ & $\begin{array}{l}0.019 \\
0.007 \\
0.003\end{array}$ & $\begin{array}{c}<0.0001 \\
\text { ns } \\
<0.0001\end{array}$ & $\begin{array}{c}<0.0001 \\
0.024 \\
<0.0001\end{array}$ \\
\hline Pleurostomatida & $\begin{array}{l}\text { Abundance } \\
\text { Biomass } \\
\text { Biomass/ciliate }\end{array}$ & $\begin{array}{l}0.002 \\
\text { ns } \\
\text { ns }\end{array}$ & $\begin{array}{l}\text { ns } \\
\text { ns } \\
\text { ns }\end{array}$ & $\begin{array}{l}0.001 \\
0.068 \\
\text { ns }\end{array}$ & $\begin{array}{c}<0.0001 \\
\mathrm{~ns} \\
\mathrm{~ns}\end{array}$ \\
\hline
\end{tabular}


variability across all 3 years (Table 5). Ciliate biomass ( $\mu \mathrm{C} \mathrm{C}^{-1}$ ) remained much more uniform than ciliate abundance over the $3 \mathrm{yr}$ period (Tables 4 \& 5). This suggests a compensatory increase in cell size when ciliate abundance declined (Tables $4 \& 5$ ).

\section{Dominant scales of variation for ciliate community abundance and biomass}

Analysis of the variance in ciliate abundance showed interannual variance to be similar to that between months ( 8 and $6 \%$ of the variance, respectively, $p<$ 0.01 and $p<0.06$, respectively). However, the seasonal pattern of ciliate abundance also differed between years, these differences accounting for a larger $(16 \%$, $p<0.001$ ) share of the variance. Yet, most of the variance in ciliate abundance occurred at time scales other than annual or monthly (i.e. $68 \%$ unexplained variance). We therefore examined the dependence of ciliate abundance on time scale using a semivariogram. The results obtained indicate a steady increase in semivariance with increasing time scale to reach a plateau at about $50 \mathrm{~d}$ (Fig. 7 a). This indicates the dominant scale of temporal variation in ciliate abundance to be about $2 \mathrm{mo}$, resulting from the interaction of the characteristic time scales of multiple processes influencing ciliate abundance. Variation in ciliate biomass is, however, buffered relative to that in numerical abundance (Fig. 7 b), since changes in ciliate density are compensated by opposite changes in mean cell size (Table 4).

\section{DISCUSSION}

The Bay of Blanes is considered a temperate oligotrophic coastal area where a late winter phytoplankton bloom (mainly diatoms, cf. Mura et al. 1996) occurs concurrent with the annual minimum temperatures. This late winter bloom appears to be a general feature of the Catalan coast, and is recurrently associated with a period of low sea level, promoted by a sustained period of atmospheric stability, characterized by high atmospheric pressure, calm waters, lack of rainfall (Cebrián et al. 1996), low biomass of herbivorous zooplankton (Andreu \& Duarte 1996), and high abundance of fish larvae (Palomera \& Olivar 1996). These fish larvae may relax the pressure mesozooplankton normally exert on microplankton. The input of organic matter during the winter bloom leads to increased abundance of bacteria and protists. However, phytoplankton (mainly dinoflagellates; Mura et al. 1996) can also bloom during the summer, with high water temperature and a stratified water column. The con-
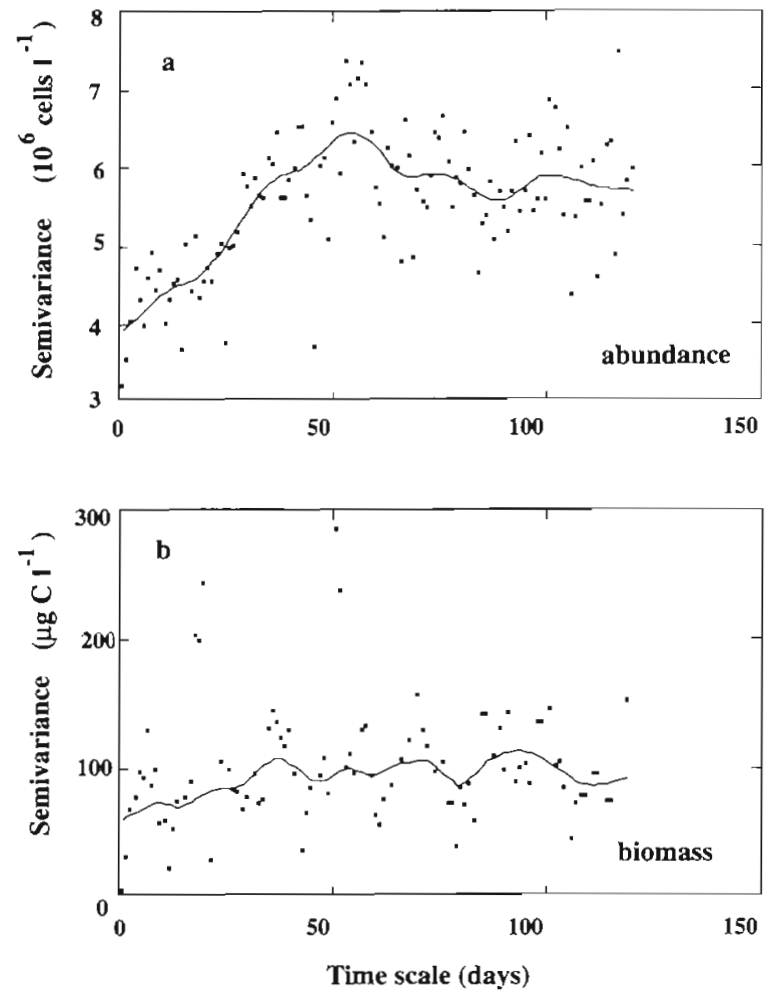

Fig. 7. Dominant scale of temporal variation in ciliate (a) abundance and (b) biomass, using a semivariogram

centration of chl a during summer time is always lower than that recorded during winter/spring (Fig. 3a). Andreu \& Duarte (1996) found an increase of zooplankton (mainly copepods and cladocerans) in August 1992 in the Bay of Blanes, which could have been responsible for the reduced abundance of phytoplankton and ciliates at the end of summer 1992. These seasonal phytoplankton blooms are similar to those observed for the Chesapeake Bay area (Dolan \& Coats 1990) and the French Mediterranean coast (FerrierPagès \& Rassoulzadegan 1994). However, the ciliate spring bloom in the Bay of Blanes appears to occur slightly earlier than these other blooms, presumably in response to the phytoplankton bloom in late winter observed in this area. Cross correlation analysis showed bacterial abundance and chl a concentration to be negatively correlated with ciliate abundance $(\mathrm{p}$ 0.05 ). These correlations indicate that an increase in ciliate abundance is associated with a decline in bacteria and phytoplankton abundance with a delay of about $2 \mathrm{wk}$, and suggests, therefore, a role for ciliates in the control of these populations. Furthermore, the monthly coefficient of variation for bacterial abundance (range: 8.9 to $80 \%$ ) was moderate in comparison with those of heterotrophic nanoflagellates (range: 26 to $106 \%$ ), and ciliates (range: 18 to $137 \%$ ). Heterotrophic nanoflagellates and ciliate abundance were 
much more variable than bacteria in the study period, as expected based on predator-prey models (Wright 1988, Vaqué \& Pace 1992). These results support the existence of seasonal differences in microplanktonic food web structure in temperate coastal areas (Pierce \& Turner 1992).

Our results also provide evidence of the importance of heavy rainfall for the abundance of bacterioplankton and heterotrophic nanoflagellates in the Bay of Blanes (Tables 1 \& 2). This response presumably reflects the increase in allochthonous inputs of DOM from river flushing after rainstorms, which promotes the growth of bacteria and, in turn, leads to an increase in heterotrophic nanoflagellate abundance. The response of ciliate abundance and biomass to heavy rainfall was not as clear as those for heterotrophic picoplankton and nanoplankton, but showed a tendency for ciliate abundance and biomass to decrease during heavy rainfall (Table 2). This observation is consistent with the results of Nielsen \& Kiørboe (1991), who observed a decrease in ciliate abundance and biovolume during wind storm periods.

The mean ciliate abundance observed in the Bay of Blanes (Table 3 ) was slightly higher than that reported for the French Mediterranean coast ( 1 to $2 \times 10^{3}$ cells $\mathrm{l}^{-1}$ ) by Ferrier-Pagès \& Rassoulzadegan (1994), but lower than values reported for more eutrophic systems (Table 6). Mean ciliate biomass and the range of biomass variation observed were higher than values reported in the literature (Table 6). The wider range of variation observed in the Bay of Blanes may simply reflect the larger number of biomass estimates available there (Table 6). The dominance by naked hetero- trophic oligotrichs of the ciliate community growing in the Bay of Blanes is in agreement with previous studies in the Mediterranean Sea (Ferrier-Pagès \& Rassoulzadegan 1994, Dolan \& Marrasé 1995) and appears to be characteristic of most marine and brackish water ecosystems (Beers et al. 1980, Smetacek 1981, Andersen \& Sorensen 1986, Sherr et al. 1986, Dolan \& Coats 1990, Nielsen \& Kiørboe 1991). Maximum values for mixotrophic oligotrichs were 1 order of magnitude higher in this coastal area (Table 3) than those in the open northwestern Mediterranean Sea (205 ciliates $\mathbf{l}^{-1}$ in June 1993; Dolan \& Marrasé 1995). These large ciliates represented about $20 \%$ of the total ciliate biomass (Table 3 ) in the Bay of Blanes, compared to about half of the ciliate biomass in the northwestern Mediterranean (Dolan \& Marrasé 1995). The relative contribution of mixotrophic oligotrichs could be underestimated in our acidic Lugol's-preserved samples, where we could only recognize 2 genera as mixotrophic (Laboea and Tontonia), although some of the ciliates we considered heterotrophic oligotrichs may also be mixotrophic (Dolan \& Marrasé 1995, and references therein).

Tintinnids were, on average, the third most abundant group, as observed on the French Mediterranean coast (Ferrier-Pagès \& Rassoulzadegan 1994). Tintinnid biomass represented only $7 \%$ of total ciliate biomass for the 3 yr period, similar to their low contribution to the ciliate community of the open northwestern Mediterranean Sea (Dolan \& Marrasé 1995). Hargraves (1981) and Verity (1987) reported strong seasonal cycles in temperate near-shore environments (Narragansett Bay, Rhode Island, USA), with tintinnid

Table 6. Mean and range (in parentheses) of ciliate abundance and biomass in different marine systems for surface waters. nc: not comparable data; nd: not determined

\begin{tabular}{|c|c|c|c|}
\hline Location & $\begin{array}{c}\text { Mean (range) } \\
\text { (ciliates } \mathrm{l}^{-1} \times 10^{3} \text { ) }\end{array}$ & $\begin{array}{l}\text { Mean (range) } \\
\quad\left(\mu g \mathrm{Cl}^{-1}\right)\end{array}$ & Source \\
\hline Sea of Japan & $(0.3-15)$ & $\mathrm{nc}$ & Sorokin (1977) \\
\hline Pacific coastal waters ${ }^{\hat{a}}$ & $11.2(5.0-24)$ & $3.6(0.8-9.0)$ & Beers et al. $(1980)$ \\
\hline Kiel Bight Estuary ${ }^{\mathrm{b}}$ & $(<0.02-92)$ & $(1.0-56)$ & Smetacek (1981) \\
\hline Oslofjord, Sweden & $(2.2-14.7)$ & nd & Paasche \& Kristiansen (1982) \\
\hline Kaneohe Bay, Hawaii, USA & $(1.0-1.4)$ & 1.96 & Landry et al. (1984) \\
\hline Limfjord Sound & $17.1 \quad(1.4-162)$ & nd & Andersen \& Sørensen (1986) \\
\hline Maine Estuary & $(<0.02->540)$ & nd & Sanders (1987) \\
\hline Open Sound, Georgia, USA & 14.0 & nd & Sherr et al. (1989) \\
\hline Tidal Creek, Georgia, USA & 71.0 & nd & Sherr et al. (1989) \\
\hline Chesapeake Bay area & $(4.0-22)$ & $(8.4-16)$ & Dolan \& Coats (1990) \\
\hline Northern Baltic & $(0.3-10.2)$ & $(0.3-4.0)$ & Leppänen \& Brunn (1986) \\
\hline Adriatic Sea & 0.88 & 0.72 & Revelante \& Gilmartin (1990) \\
\hline NW Mediterranean Sea & $(1-2)$ & $(0.2-1.2)$ & $\begin{array}{l}\text { Ferrier-Pagès \& } \\
\text { Rassoulzadegan (1994) }\end{array}$ \\
\hline Blanes Bay (NW Med.) & $3.81(0.13-26)$ & $5.37(0.031-96)$ & This study \\
\hline
\end{tabular}


abundance fluctuating between $10^{2}$ and $10^{4}$ cells $\mathrm{l}^{-1}$. This was not the case in the Bay of Blanes, where no clear seasonality in tintinnid abundance, which was generally low, was observed. Tintinnid abundance fluctuated greatly at short scales of 1 to 2 wk (coefficient of variation of monthly tintinnid abundance ranged from $36 \%$ in January 1994 to $224 \%$ in August 1993). These short-term fluctuations appear to be characteristic of this group (Gold \& Morales 1976, Graziano 1989) and may reflect the confounding effect of patchiness (Stoecker et al. 1984). The biomass of tintinnids presented even broader temporal fluctuations than their abundance (coefficient of variation of monthly tintinnid biomass ranged from 30\% in August 1994 to $264 \%$ in August 1992).

The orders Scuticociliatida and Pleurostomatida were much less abundant than the aforementioned groups, as has been described for other parts of the Mediterranean Sea (Ferrier-Pagès \& Rassoulzadegan 1994, Dolan \& Marrasé 1995) and other marine systems such as Chesapeake Bay (Dolan \& Coats 1990). The abundance of Mesodinium in the Bay of Blanes was significantly greater than that observed in the

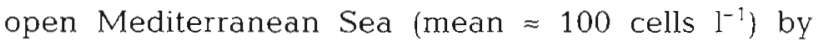
Dolan \& Marrasé (1995). The lack of a significant correlation between Mesodinium abundance and biomass and chl a concentration is also similar to reports from the open Mediterranean Sea (Dolan \& Marrasé 1995).

The bulk of the ciliate community, represented by naked oligotrichs, showed a seasonal pattern characterized by spring peaks, as well as peaks in summer 1.992 and 1993, and in autumn 1993 and 1994. The seasonal patterns of tintinnids, Scuticociliatida, Pleurostomatida and Mesodinium were distinctly different, suggesting that each group responds differently to changes in the environment and food web.

Although total ciliate abundance and biomass were significantly correlated, this correlation was weak, resulting in mostly independent seasonal trends for total ciliate abundance and biomass. A similar difference between the seasonal patterns between ciliate abundance and biomass has been reported for Chesapeake Bay by Dolan \& Coats (1990).

The interannual differences in ciliate abundance and cell size were much larger than those in total ciliate biomass ( $\mu \mathrm{g} \mathrm{C}^{-1}$ ), due to a compensatory increase in cell size when abundance declined (Tables 4 \& 5). Differences among years had a modest contribution $(16 \%$ of the variance) to the temporal variation in ciliate abundance. We found that the dominant time scale for ciliate abundance variability was about $50 \mathrm{~d}$, similar to that of chl a concentration in the Bay of Blanes (Prairie \& Duarte 1996). In contrast, the variation in ciliate biomass was independent of the time scale, with as much variance in ciliate biomass at short sampling intervals as at the interannual scale (Fig. 7b).

In summary, the results presented provide additional information on the temporal variability of ciliate abundance, biomass and composition in an oligotrophic coastal area. Oligotrich ciliates dominated the community throughout the study period, during which no simple seasonal or annual pattern for ciliate abundance and biomass was observed. The abundance of ciliates showed a dominant time scale of variation of about $50 \mathrm{~d}$, while the variation in biomass was similar across the time scales resolved in this study. These results suggest a complex control of ciliate abundance and, particularly, biomass by the interaction of environmental (e.g, rainfall and temperature) and biological (e.g. prey and predator abundance) processes. The net result of this complex regulation is a complex pattern of change in ciliate abundance, and a uniform biomass, only weakly related to the underlying forcing factors.

Acknowledgements. This research was funded by the grants MAR-91-0503 and AMB94-AMB94-0746 of the Spanish Interministerial Commission of Science and Technology (CICYT). We are grateful to A. Pardo, I. Trepat, and $M$. Rafel for their enthusiastic technical assistance, and to $S$. Agustí, G. Carreras, J. Cebriàn, P. Mura, P. Satta, and B. Vidondo for assistance with sampling.

\section{LITERATURE CITED}

Aladro Lubel MA, Martínez Murillo ME, Mayén Estrada R (1990) Manual de ciliados psamófilos marinos y salobres de Mexico. In: Lot Helgueras A, Bueno Soria J, Novelo Retana A, Johansen Naime RM (eds) Cuadernos 9. Instituto de Biología, Universidad Nacional Autonoma de Mexico, Mexico, p 174

Andersen P, Sorensen HM (1986) Population dynamics and trophic coupling in pelagic microorganisms in eutrophic coastal waters. Mar Ecol Prog Ser 33:99-109

Andreu P, Duarte CM (1996) Zooplankton seasonality in the Bay of Blanes (NW Mediterranean). In: Duarte CM (ed) Seasonality in the Bay of Blanes: a paradigm of the northwest Mediterranean littoral. Vol 22. Publications of the Spanish Oceanographic Institute, Madrid (in press)

Azam F, Fenchel T, Field JG, Gray JS, Meyer-Reil LA, Thingstad $F$ (1983) The ecological role of water column microbes in the sea. Mar Ecol Prog Ser 10:257-263

Beers JR, Reid FMH, Stewart GL (1980) Microplankton population structure in southern California near shore waters in late spring. Mar Biol 60:209-226

Bernard C, Rassoulzadegan F (1994) Seasonal variations of mixotrophic ciliates in the northwest Mediterranean Sea. Mar Ecol Prog Ser 108:295-301

Cebriàn J, Duarte CM. Pascual J (1996) Marine climate in the Costa Brava (NW Mediterranean) littoral. In: Duarte $C M$ (ed) Seasonality in the Bay of Blanes: a paradigm of the northwest Mediterranean littoral. Vol 22. Publications of the Spanish Oceanographic Institute, Madrid (in press)

Dolan JR, Coats DW (1990) Seasonal abundances of planktonic ciliates and microflagellates in mesohaline Chesapeake Bay waters. Estuar Coast Shelf Sci 31:157-175 
Dolan JR, Marrasé C (1995) Planktonic clliate distribution relative to a deep chlorophyll maximum: Catalan Sea, NW Mediterranean, June 1993. Deep Sea Res 42:1965-1987

Ferrier-Pagès C, Rassoulzadegan F (1994) Seasonal impact of the microzooplankton on pico- and nanoplankton growth rates in the northwest Mediterranean Sea. Mar Ecol Prog Ser 108:283-294

Gold K. Morales E (1976) Studies on the sizes, shapes, and development of the lorica of agglutinated tintinnids. Biol Bull Mar Biol Lab Woods Hole 150:377-392

Graziano C (1989) On the ecology of tintunnids (Ciliophora: Oligotrichida) in the North Irish Sea. Estuar Coast Shelf Sci 29:233-245

Hargraves PE (1981) Seasonal variation of tintinnids (Ciliophora, Oligotrichida) in Narragansett Bay, Rhode Island USA. J Plankton Res 3:81-91

Landry MR, Haas LW, Fagerness VL (1984) Dynamics of microbial plankton communities: experiments in Kaneohe Bay, Hawaii. Mar Ecol Prog Ser 16:127-133

Leakey RJG, Burkill PH, Sleigh MA (1994) A comparison of fixatives for the estimation of abundance and biovolume of marine planktonic ciliate populations. J Plankton Res 16(4):375-389

Lee JJ, Hunter SH, Bovee EC (1985) An illustrated guide to the protozoa. Society of Protozoologists, Lawrence, KS, p 629

Leppänen JM, Brunn JE (1986) The role of pelagic ciliates including the autotrophic Mesodinium rubrum during the spring bloom of 1982 in the open Northern Baltic proper Ophelia (Suppl) 4:147-157

Masó M, La Violette PE, Tintoré J (1990) Coastal flow modification by submarine canyons along the NE Spanish coast. Scientia Mar 54(4):343-348

Masó M, Tintoré J (1991) Variability of the shelf water off the northeast Spanish coast. J Mar Sys 1:441-450

Mura MP, Agustí S, Cebriàn J, Satta MP (1996) Seasonal variability of phytoplankton biomass and community composition of Blanes Bay (1992-1994). In: Duarte CM (ed) Seasonality in the Bay of Blanes: a paradigm of the northwest Mediterranean hittoral. Vol 22. Publications of the Spanish Oceanographic Institute, Madrid (in press)

Nielsen TG, Kiorboe T (1991) Effects of a storm event on the structure of the pelagic food web with special emphasis on planktonic ciliates. J Plankton Res 13(1):35-51

Paasche $E$, Kristiansen $S$ (1982) Ammonium regeneration by microzooplankton in the Oslofjord. Mar Biol 69:55-63

Palomera I. Olivar P (1996) Nearshore Ichthyoplankton off Costa Brava (Northwestern Mediterranean). In: Duarte CM (ed) Seasonality in the Bay of Blanes: a paradigm of the northwest Mediterranean littoral. Vol 22. Publications of the Spanish Oceanographic Institute, Madrid (in press)

Parsons TR, Maita Y, Lalli CM (1984) A manual of chemical and biological methods for seawater analysis. Pergamon Press, Oxford, p 173

Responsible Subject Editor: J. Dolan, Villefranche-sur-Mer, France
Pierce RW, Turner JT (1992) Ecology of planktonic ciliates in marine food webs. Rev Aquat Sci 6(2):139-181

Porter KG, Feig YS (1980) The use of DAPl for identifying and counting aquatic microflora. Limnol Oceanogr 25:943-948

Prairie YT, Duarte CM (1996) Weak density-dependence and short-term perturbations as determinants of phytoplankton temporal dynamics. Ecosclence (in pres5)

Putt $M$. Stoecker DK (1989) An experimentally determined carbon:volume ratio for marine oligotrichous ciliates from estuarıne and coastal waters. Limnol Oceanogr 34: 1097-1104

Revelante N, Gilmartin M (1990) Vertıcal water column resource partitioning by a ciliated protozoan population under stratufied conditions in the northern Adriatic. J Plankton Res 12(1):89-107

Robertson GP (1987) Geostatistics in ecology: interpolating with known variance. Ecology 68:744-748

Sanders RW (1987) Tintinnids and other microzooplankton seasonal distributions and relationships to resources and hydrography in a Maine estuary. J Plankton Res 9(1): $65-77$

Satta MP, Agustí S, Mura MP, Vaqué D, Duarte CM (1996) Microplankton respiration and net community metabolism in a bay on the NW Mediterranean. Aquat Microb Ecol 10: $165-172$

Sherr BF, Sherr EB, Pedrós-Alió C (1989) Simultaneous measurement of bacterioplankton production and protozoan bacterivory in estuarine water Mar Ecol Prog Ser 54: $209-219$

Sherr EB, Sherr BF, Fallon RD, Newell S (1986) Small aloricate ciliates as a major component of the marine heterotrophic nanoplankton. Limnol Oceanogr 31:177-183

Smetacek V (1981) The annual cycle of protozooplankton in the Kiel Bight. Mar Biol 63:1-11

Sorokin YI (1977) The heterotrophic phase of plankton succession in the Japan Sea. Mar Bial 41:107-117

Stoecker DK, Gifford DJ, Putt M (1994) Preservation of marine planktonic caliates: losses and cell shrinkage during fixation. Mar Ecol Prog Ser 110:293-299

Stoecker DK, Davis LH, Anderson DM (1984) Fine scale spatial correlations between planktonic ciliates and dinoflagellates. J Plankton Res 6:829-842

Vaqué D, Pace ML (1992) Grazing on bacteria by flagellates and cladocerans in lakes of contrasting food web struc. ture. J Plankton Res 14:307-323

Verity PG (1987) Abundance, community composition, size distribution, and production rates of tintinnids in Narragansett Bay, Rhode Island. Estuar Coast Shelf Sci 24:671-690

Verity PG, Langdon C (1984) Relationships between lorica volume, carbon, nitrogen, and ATP content of tintinnids in Narragansett Bay. J Plankton Res 6:859-868

Wright RT (1988) A model for short-term control of the bacterioplankton by substrate and grazing. Hydrobiologia 159 : $111-117$

Manuscript first received: October 16, 1995 Revised version accepted: October 30, 1996 